\title{
Mixed species aggregations feeding upon herring and sandlance schools in a nearshore archipelago depend on flooding tidal currents
}

\author{
Jeannette E. Zamon ${ }^{1,2, *}$ \\ ${ }^{1}$ Department of Ecology \& Evolutionary Biology, University of California, Irvine, California 92697-2525, USA \\ ${ }^{2}$ Present address: NOAA Fisheries/Point Adams Field Station, PO Box 155 (520 Heceta Place), Hammond, \\ Oregon 97121-0155, USA
}

\begin{abstract}
Tidal rips and jets are common features associated with archipelagos and complex coastlines. In habitats where rips and jets develop, energy flow to piscivorous predators is hypothesized to be strongly associated with tidal phase due to interactions between currents, plankton, and schooling planktivorous fishes (the 'tidal coupling hypothesis'). This study tests 1 component of the tidal coupling hypothesis, that the feeding activity of piscivorous predators and the availability of planktivorous fishes are both strongly associated with the same tidal phase. During 1994 to 1997, I made visual counts of actively feeding, mixed-species seabird flocks and hydroacoustic measurements of the relative abundance and distribution of schooling fishes. Median feeding activity, median backscatter $\mathrm{m}^{-1}$ transect, and median prey encounter probabilities were greatest during the tidal periods Slow flood 1 and Fast flood. Positive feeding anomalies and positive prey-encounter anomalies were significantly associated with tidal flood phases, but positive backscatter anomalies were not. The results support the tidal-coupling hypothesis, but suggest that changes in the distribution or behavior of schooling fish are as important as, if not more important than, changes in relative fish abundance when determining prey availability and predator foraging-success. The data show that tidal currents can play an important role in structuring nearshore predator-prey interactions.
\end{abstract}

KEY WORDS: Tidal currents · Physical-biological coupling · Predator-prey dynamics · Seabirds · Herring $\cdot$ Sandlance $\cdot$ San Juan Islands

\section{INTRODUCTION}

Tidal rips and jets are common physical features of archipelagos and complex coastlines. These features form when tidal currents flow past headlands, promontories, or steep-sided channels. Several authors have put forward the hypothesis that in habitats where rips and jets are present, energy flow to piscivorous predators is strongly associated with tidal phase (e.g. Uda \& Ishino 1958, Brown 1980, Johannes 1981, Wolanski \& Hamner 1988, review in Hunt et al. 1999, Zamon 2001); hereafter this will be referred to as 'tidal-coupling hypothesis'. The mechanism is thought to operate as follows: current-coastline interactions create tempo- rally and spatially predictable rips and jets, which create predictable changes in zooplankton distribution, abundance, or delivery rate. Planktivorous fishes then aggregate to feed in times or places with increased plankton densities or plankton delivery rates. In turn, these feeding aggregations of fishes attract piscivorous predators. Therefore, feeding activity in piscivorous predators is predicted to be strongly coupled to the daily tidal cycle (Wolanski \& Hamner 1988). However, no published studies have explicitly and quantitatively examined tidal variation in all 3 trophic links.

This study tested the tidal-coupling hypothesis by breaking it into the component trophic interactions. I sought to answer the following questions: (1) Do pisci- 
vorous predators show tidal changes in feeding activity? (2) Do planktivorous schooling fishes show tidal changes in distribution or abundance that significantly alter their availability to predators? (3) Do plankton eaten by planktivorous fishes show tidal changes in distribution or abundance that significantly alter their availability to planktivorous fishes? To answer Questions 1 and 2, I collected and analyzed data on (1) tidal variation in counts of mixed-species seabird flocks that were feeding upon juvenile Pacific herring Clupea harengus and juvenile Pacific sandlance Ammodytes hexapterus, and (2) tidal variation in the distribution and relative abundance of fish schools as measured with hydroacoustics. The analyses of tidal variation in copepod abundance relevant to the third question have been presented in a separate publication (Zamon 2002).

\section{MATERIALS AND METHODS}

Study site. I chose to work in the San Juan Islands, Washington State, USA, because this archipelago is known for its complex topography, strong tidal currents, and abundant marine life. The San Juan Islands are located between eastern Juan de Fuca Strait and southern Georgia Strait (Fig. 1). The archipelago is part of a larger complex including the Gulf Islands of
British Columbia, Canada. These islands experience semidiurnal, unequal tides, with flood currents moving approximately northward through the archipelago and ebb currents moving approximately southward. During summer, large numbers of seabirds, marine mammals, and fishes occur in the nearshore waters of this archipelago (Lewis \& Sharpe 1987). Many of these animals are believed to feed primarily in areas of strong tidal currents (Lewis \& Sharpe 1987, Suryan \& Harvey 1998, Zamon 2001). Cattle Pass, the channel between southern San Juan and Lopez Islands, was chosen as a focal study site. This channel is typical of many channels in the San Juan Islands/Gulf Islands region: it is narrow $(0.7 \mathrm{~km}$ across at its greatest constriction), has steep sides (dropping $100 \mathrm{~m}$ in depth over horizontal distances of 10 to $20 \mathrm{~m}$ ), and experiences strong surface currents (up to $>3 \mathrm{~m} \mathrm{~s}^{-1}$ in surface jets: J. E. Zamon unpubl. data). The area is known to local naturalists as often containing large aggregations of piscivorous seabirds (Lewis \& Sharpe 1987).

Operational definition of a feeding flock. Counts of mixed-species feeding aggregations, composed primarily of seabirds, provided a direct measure of apex predator feeding activity on planktivorous fishes. Actively feeding flocks are easily distinguished by sight or sound from non-feeding groups of birds. I defined an actively feeding flock as 5 or more seabirds aggregated over a visually well-defined and typically

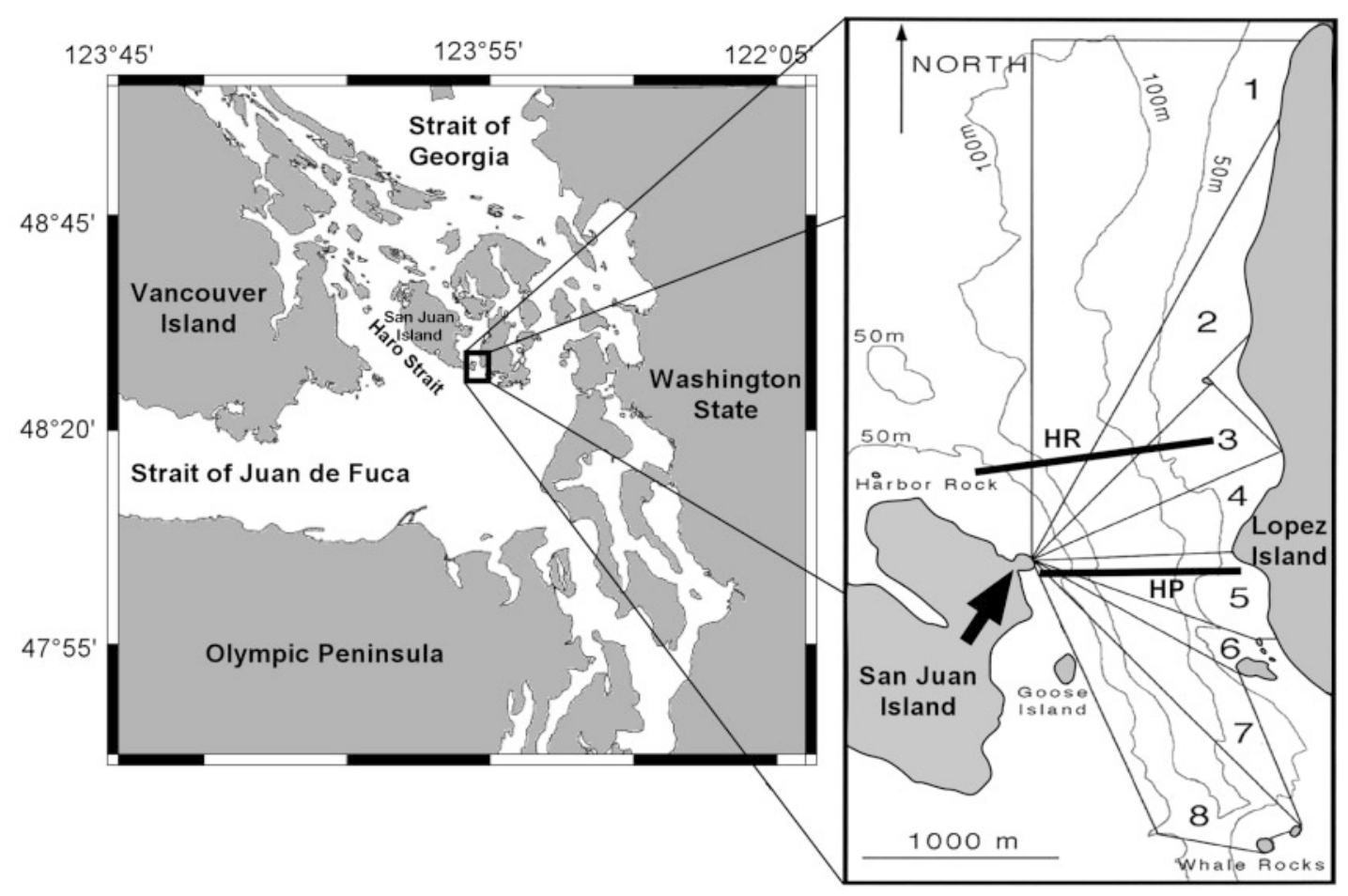

Fig. 1. Study site, showing 8 sectors and 2 cross-channel transects (HR and HP) covered by this study. Latitude and longitude are in degrees north and west, respectively. Land-based observation point is indicated by black arrow 


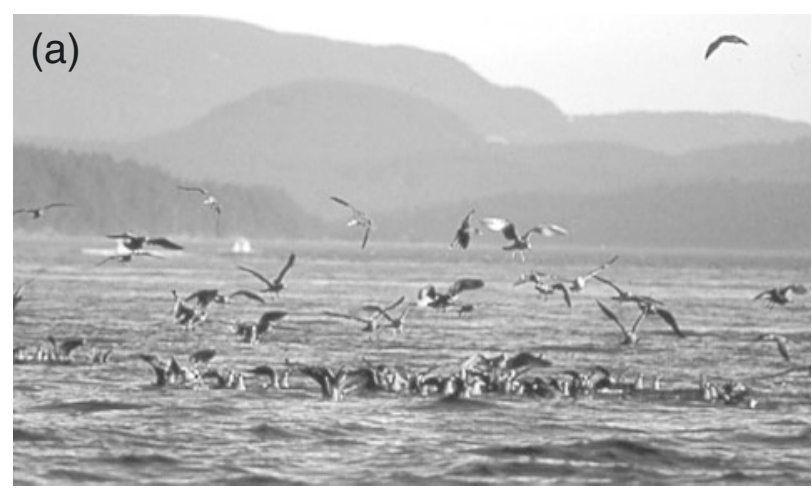

(b)

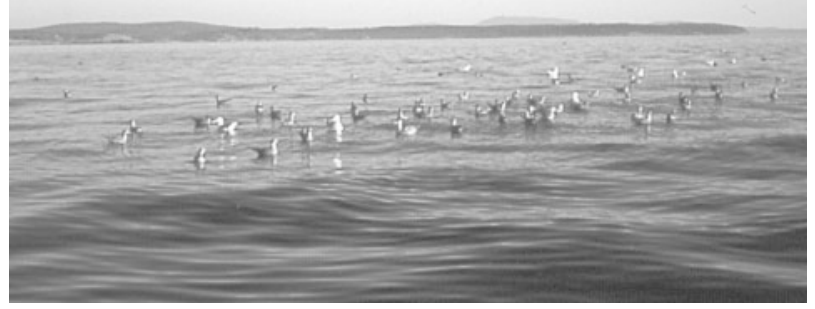

Fig. 2. (a) Actively feeding and (b) non-feeding flocks of observed to have any effect on flock behavior (e.g. causing flushing or diving behaviors), probably because birds are habituated to frequent small-plane traffic in the area. The same route around and between the islands was flown during maximum flood and maximum ebb currents on each of 3 survey days (Fig. 3). Flocks were also counted on 4 additional maximum flood tides. Flock positions were recorded on a nautical chart of the region. Comparisons between flood and ebb flock-counts were made with an unpaired signtest to determine whether or not the number of feeding flocks differed between tides.

Feeding-flock activity: land-based counts. Landbased observations of seabird feeding activity were made during June through September of 1994 to 1997. I made observations from a lookout on the SE tip of San Juan Island, approximately $7 \mathrm{~m}$ above sea level (Cattle Pass area; $48^{\circ} 28.7^{\prime} \mathrm{N}, 122^{\circ} 57.1^{\prime} \mathrm{W}$, Fig. 1). I used $8 \times 24$ power binoculars to continuously scan 8 unequal-sized spatial sectors covering a total area of approximately $5.5 \mathrm{~km}^{2}$ of sea surface (Fig. 1). Sector boundaries coincided with prominent fixed landmarks such as rocks, trees, or houses. I used a software package to predict current velocities a priori, and then to select $30 \mathrm{~min}$ long sampling periods covering all possible tidal-phase circular area on the surface of the water. Most birds in this area were within $<2$ body lengths of each other. Birds in an active feeding flock were also vocalizing, plunging, dipping, or diving, whereas birds in a resting or inactive flock were silent, resting and drifting on the water's surface (Fig. 2). In the San Juan Islands, I have only seen mixed-species flocks when seabirds are feeding upon schooling forage fishes (Pacific herring or Pacific sandlance) or upon bits of fish flesh associated with harbor seals consuming adult salmon (Oncorhynchus spp.). Flocks associated with sealsalmon interactions can be distinguished from flocks associated with forage fishes (see Zamon 2001 for details and separate analyses of these types of flocks). Because flocks associated with seal-salmon interactions are not directly associated with forage fishes, they were not included in this analysis.

Feeding-flock activity: aerial counts. As part of a pilot study in 1994, I counted feeding flock abundance during aerial surveys of the whole San Juan archipelago. Counts of flocks were made from a seaplane flying approximately 150 to $200 \mathrm{~m}$ above sea level. Flight speeds were approximately $100 \mathrm{~km} \mathrm{~h}^{-1}$ over a 50 min flight. Seaplane surveys were not

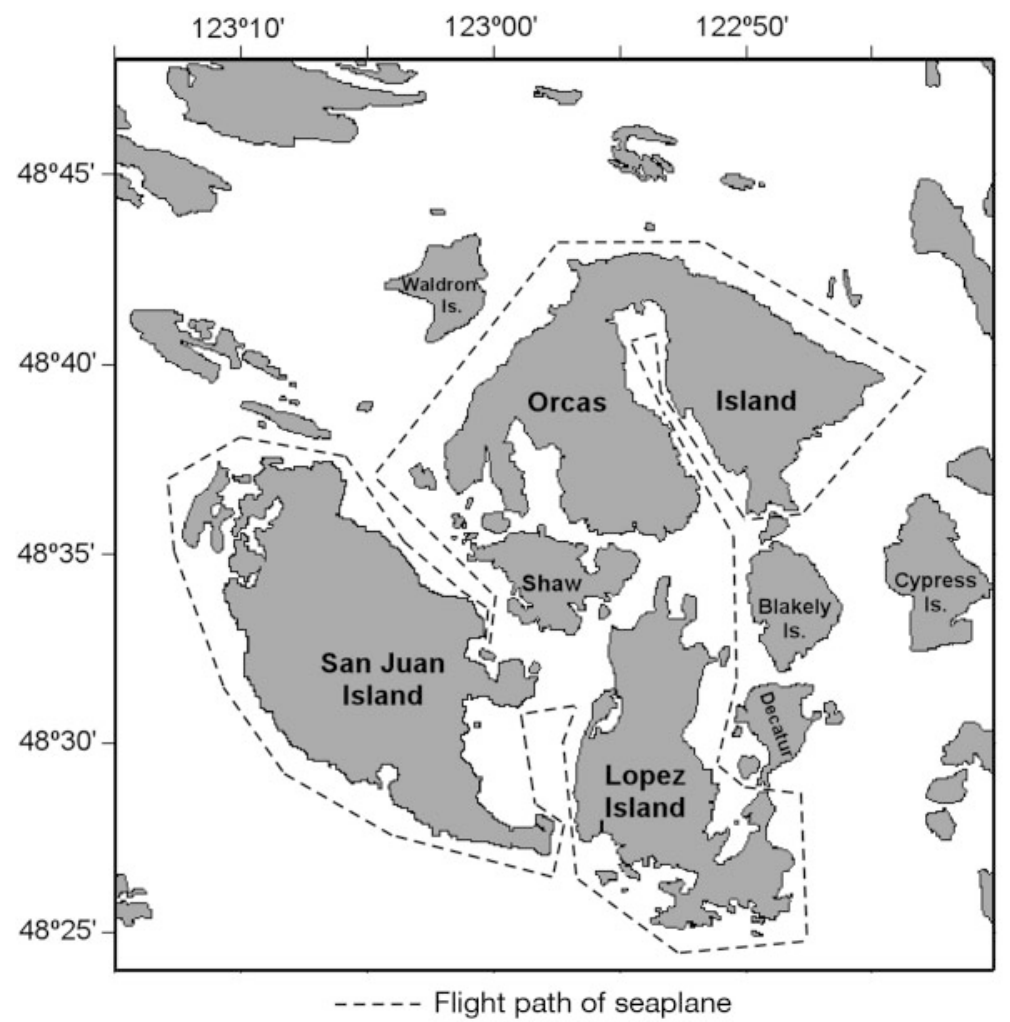

Fig. 3. Path of aerial survey of San Juan Islands. The seaplane was traveling clockwise along flight path. Latitude and longitude are in degrees north and west, respectively 
Table 1. Classification of tidal velocities: positive velocities represent flood currents, negative velocities ebb currents. Categories from Braune \& Gaskin (1982)

\begin{tabular}{|lc|}
\hline Tidal phase & Predicted current velocity \\
\hline Slack low & -0.25 to $+0.25 \mathrm{~m} \mathrm{~s}^{-1}$ \\
Slow flood 1 & +0.26 to $+1 \mathrm{~m} \mathrm{~s}^{-1}$ \\
Fast flood & $>+1 \mathrm{~m} \mathrm{~s}^{-1}$ \\
Slow flood 2 & +1 to $+0.26 \mathrm{~m} \mathrm{~s}^{-1}$ \\
Slack high & +0.25 to $-0.25 \mathrm{~m} \mathrm{~s}^{-1}$ \\
Slow ebb 1 & -0.26 to $-1 \mathrm{~m} \mathrm{~s}^{-1}$ \\
Fast ebb & $<-1 \mathrm{~m} \mathrm{~s}^{-1}$ \\
Slow ebb 2 & -1 to $-0.26 \mathrm{~m} \mathrm{~s}^{-1}$ \\
\hline
\end{tabular}

and time-of-day combinations (Nautical Software 1996). I used scan-sampling techniques to count feeding flocks occurring in each 30 min observation period (Altmann 1974). I recorded the time at which each flock was first seen. When possible, I also counted and identified the species of all individuals in a flock.

Each 30 min observation period was assigned to a tidal-phase category based on predicted current velocities (Table 1) sensu Braune \& Gaskin (1982). If current velocities within an observation period changed from one category to another, then that observation was assigned to a category based on the current velocity at the beginning of the period. Observation periods in which visibility became reduced in any sector (e.g. due to fog or rough seas) were excluded from the analysis.

Variation in feeding activity could be affected by events occurring at timescales other than that of a tidal cycle (e.g. day-to-day, fortnightly, seasonal, or interannual scales). To minimize the variation contributed by non-tidal signals, all counts of feeding flocks were coded as either greater than, equal to, or less than the median count for the day on which the observations took place. Hereafter, I refer to counts greater than the daily median as 'positive feeding anomalies' and counts less than the daily median as 'negative feeding anomalies'. Although the raw data are also reported in this manuscript, only anomaly data were used in the statistical analysis of tidal variation.

To determine whether feeding anomalies were significantly associated with tidal phase, I used a chisquare goodness-of-fit test (2-way median test) to examine the null hypothesis that there was no association between feeding anomalies and tidal phase (Sokal \& Rolf 1995). A goodness-of-fit test was chosen over parametric techniques because raw-count data were not normally distributed, sample sizes among categories were unbalanced, and because 18.1 to $53.4 \%$ of the raw counts within a tide category were zero counts. Observations were classified within an $8 \times 2$ contingency table where the 2 factors were tidal phase (8 classes: Table 1 ) and feeding activity (2 classes: nega- tive feeding anomalies, positive feeding anomalies). Counts equal to daily medians were excluded from the goodness-of-fit analysis because they provide no statistical information about variability among tidal phases.

Interpretation of temporal patterns in seabird feeding was possibly complicated by the behavior of rhinoceros auklets Cerorhinca monocerata, diving piscivorous seabirds which breed at this time of year. Breeding rhinoceros auklets feed their nestlings only after sunset (Wilson \& Manuwal 1986), and auklets might therefore be expected to increase foraging activity in the late afternoon and evening. Any significant increase in auklet feeding activity could in turn increase the number of feeding flocks counted in the afternoon and evening because auklet hunting behavior can increase forage-fish availability to other birds (see Grover \& Olla 1983). Furthermore, because flood tides occur more often in the afternoon and evening during summer $\left(\chi^{2}=122.3\right.$, df $=21, \mathrm{p}<0.0001$; see Zamon 2001), an evening peak in auklet activity could cause an apparent tidal pattern in the frequency of feeding flocks, i.e. more feeding flocks during flood tides.

While a direct determination of whether or not auklets increase their feeding activity in the evening was not possible, it was possible to test for a significant association of feeding anomalies with time of day while holding tidal phase constant for flood tides. For this analysis, I used an $8 \times 2$ goodness-of-fit test to compare feeding anomalies versus time of day for data during the flood tides only $(\mathrm{n}=225)$. Observations were assigned to one of seven $2 \mathrm{~h}$ segment categories (before 08:00 h, 08:00 to 09:59 $\mathrm{h}, \ldots, 18: 00$ to $19: 59 \mathrm{~h}$ ). Although positive feeding anomalies had a tendency to occur more often than expected between 18:00 and 19:59 h (observed positive anomalies $=32$, expected positive anomalies $=24.2$ ), this did not result in a strongly significant association of feeding activity with time of day $\left(\chi^{2}=11.35\right.$, $\left.d f=6, p=0.078\right)$. Given the relatively large sample sizes in each time of day category (Table 2), I interpreted the p-value of 0.078 to mean that diel patterns in auklet foraging behavior did not significantly confound the interpretation of temporal patterns in this study.

Prey availability. During July through September of 1995 to 1996 and July through August of 1997, hydroacoustic equipment was available to measure relative fish abundance in the area where feeding-activity was being observed. Data were collected with a downward-facing, BioSonics DT4000 single-beam digital echosounder along 2 cross-channel transects, HR and HP (Fig. 1). I used a $6^{\circ}$ beamwidth, $120 \mathrm{kHz}$ transducer, appropriate for measuring relative abundance of forage-fishes (Horne \& Clay 1998). This frequency has 
been used to survey young-of-the-year (YOY) herring and sandlance biomass in Alaska (Thomas et al. 2002). The transducer was deployed slightly aft of amidships on the starboard side, 0.3 to $0.6 \mathrm{~m}$ below the sea surface on a fixed-mount pipe attached to the research vessel (a $4 \mathrm{~m}$ Boston whaler). In this position, the transducer was kept away from bow and stern bubbles generated as the vessel moved through the water. Data were collected at 2 pings $\mathrm{s}^{-1}$ from ranges greater than $2 \mathrm{~m}$ from the transducer face. The noise threshold was set to $-70 \mathrm{~dB}$. Average speed-over-ground during data collection was $3 \mathrm{~m} \mathrm{~s}^{-1}$. Time of day and latitudelongitude positions from a global positioning unit were recorded onto a laptop computer simultaneously with acoustic data for later processing and analysis. The speed and distance traveled along each transect were calculated from latitude and longitude data associated with each data file. It took between 8 and $10 \mathrm{~min}$ to complete 1 transect. The majority of transects were surveyed at the same time that bird observations were being made.

Each completed transect was considered an independent sampling unit. Acoustic data were processed into 20-ping horizontal reports ( $\sim 30 \mathrm{~m}$ resolution) and $1 \mathrm{~m}$ depth strata with the software Visual Analyzer v3.1 (BioSonics 1998). While the vessel was underway, visual examination of sea-surface features and echograms revealed that the transducer occasionally crossed a bubble cloud generated by vortices shed from the channel walls (see Farmer et al. 1995), from diving birds (J. E. Zamon pers. obs.), or from boat wakes (J. E. Zamon pers. obs.). The times or ping numbers of these events were noted in the transect logbook, and backscatter from these bubble clouds was removed from the data matrix before analysis. As is customary with acoustic signals which vary over several orders of magnitude, acoustic backscatter data were transformed from the logarithmic units $(\mathrm{dB})$ reported by the sounder into the linear domain $\left(\sigma_{\mathrm{bs}}\right)$ for all analyses (see Medwin \& Clay 1998). Transect data were processed between fixed east and west endpoints of the transect, although transects varied slightly in absolute length due to the difficulty of navigating along precisely the same transect line under varying current and vessel-traffic conditions. To account for any inequality in transect lengths, backscattering data were normalized as backscattering $\left(\sigma_{\mathrm{bs}}\right)$ per horizontal meter of transect before analysis.

Echograms indicated that echoes from pelagic fish schools, and not from large individual fishes, were the primary source of backscatter (Fig. 4). I assumed that acoustic backscatter was dominated by, and proportional to, the relative abundance of herring and sandlance in the water column. Several lines of direct and indirect evidence support the assumption that herring and sandlance, and not other species, were the dominant source of sound scatter in the study area: First, pelagic summer fish assemblages in the San Juan region are dominated by YOY herring and sandlance (Fresh 1979). Other schooling species are found in the area, including the 3-spined stickleback Gasterosteus aculeatus, surf smelt Hypomesus pretiosus, longfin smelt Spirinchus thaleichthys, Pacific tom cod Microgadus proximus, and yellow shiner perch Cymatogaster aggregata. However, these species are 2 to 3 orders of magnitude less abundant than herring and sandlance (Fresh 1979; and present Table 3). More recently, trawl samples in northern Skagit Bay/Deception Pass, a site $27 \mathrm{~km}$ to the east with similar physical characteristics to the Cattle Pass area, also showed that YOY herring and sandlance dominated summer pelagic catches in 2001 and 2002 (C. Rice, NOAA Fisheries, unpubl. data). Second, dip-net samples taken directly from 32 actively feeding flocks (of the 2134 flocks seen in total) caught only YOY herring and sandlance (Zamon 2001). The size ranges of fishes captured with dip nets were similar to those reported by Fresh (1979) (J. E. Zamon unpubl. data). Third, 5 deployments of an underwater camera drifting through clouds of acoustic targets showed herring or

Table 2. Contingency table, feeding anomaly versus time of day, flood tides only. For flood tides, null hypothesis of no association of feeding anomaly with time of day was not rejected $\left(\chi^{2}=11.35, \mathrm{df}=6, \mathrm{p}=0.078\right.$ )

\begin{tabular}{|c|c|c|c|c|c|}
\hline \multirow[t]{2}{*}{ Time of day (h) } & \multicolumn{2}{|c|}{ Negative feeding anomalies } & \multicolumn{2}{|c|}{ Positive feeding anomalies } & \multirow[t]{2}{*}{ Totals } \\
\hline & Observed & Expected & Observed & Expected & \\
\hline Before 08:00 & 1 & 2.4 & 6 & 4.6 & 7 \\
\hline 08:00-09:59 & 9 & 6.9 & 11 & 13.1 & 20 \\
\hline $10: 00-11: 59$ & 16 & 13.9 & 24 & 26.1 & 40 \\
\hline $12: 00-13: 59$ & 19 & 18.1 & 33 & 33.9 & 52 \\
\hline $14: 00-15: 59$ & 13 & 12.1 & 20 & 22.9 & 35 \\
\hline $16: 00-17: 59$ & 15 & 11.8 & 21 & 22.2 & 34 \\
\hline $18: 00-19: 59$ & 5 & 12.8 & 32 & 24.2 & 37 \\
\hline Totals & 78 & 78 & 147 & 147 & 225 \\
\hline
\end{tabular}




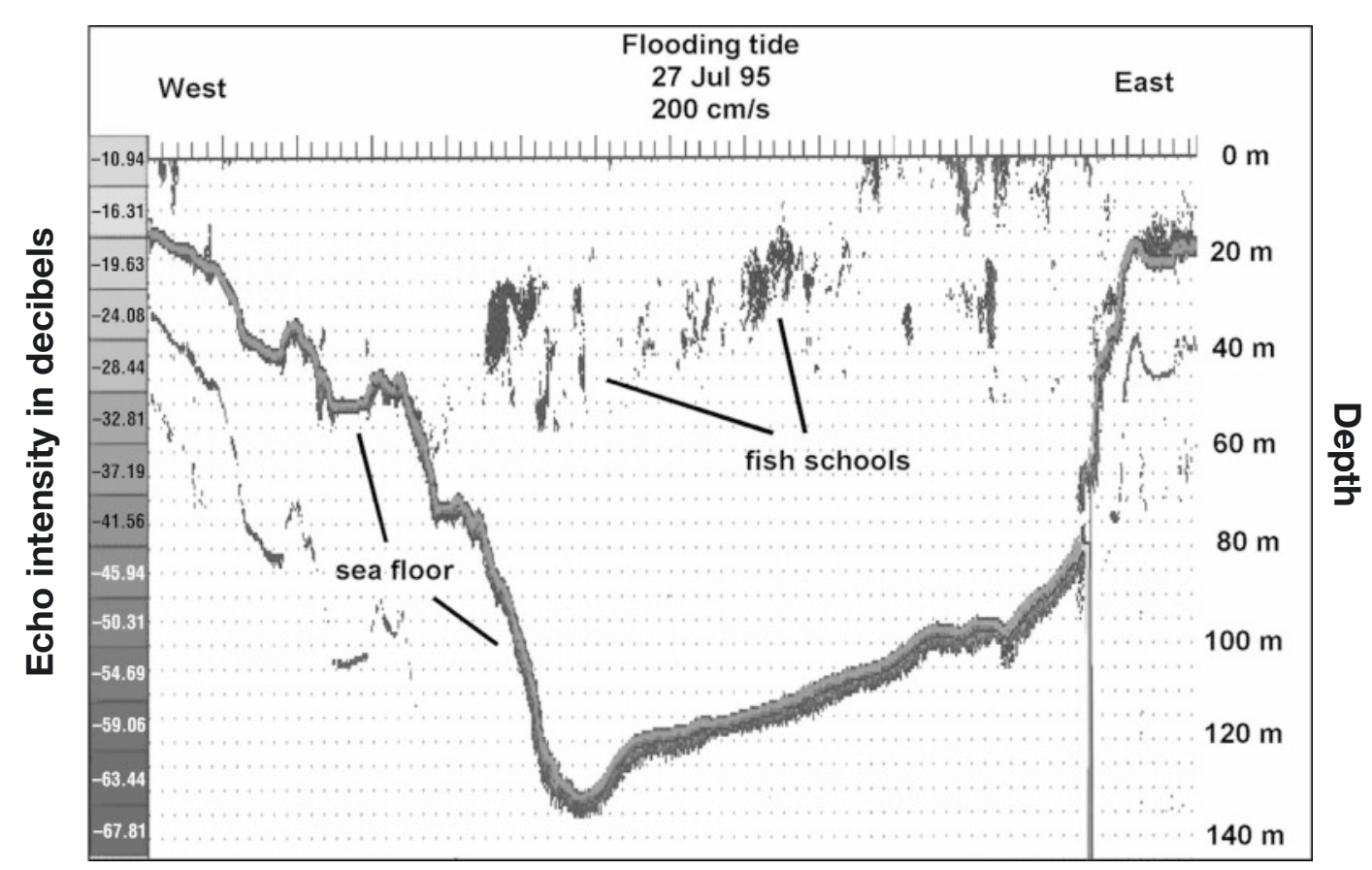

Fig. 4. Example of an echogram on HR transect. In this cross-section of southern San Juan Channel, flood tides flow into the page (northward). Transect width is approximately $1 \mathrm{~km}$

sandlance on the video. Disoriented euphausiids were never seen on the video, near the surface, or caught in plankton nets, as has been the case in other studies where euphausiids in high-current environments were

Table 3. Relative abundance of dominant fish species captured by fine-mesh surface trawls during summer months (July, August, September) in the San Juan Islands in 1974, 1975 and 1976. Data from Fresh (1979: his Table 12, p. 46); 5 sites in the San Juans were visited monthly in 1974,1975, and 1976. Catch per unit effort (CPUE) defined as number of fishes captured per number of 10 min long trawls completed.

See Fresh (1979) for details of data-collection methods

\begin{tabular}{|lr|}
\hline Species & CPUE \\
\hline Pacific herring Clupea harengus & 1319.4 \\
Pacific sandlance Ammodytes hexapterus & 181.6 \\
Pacific tomcod Microgadus proximus & 4.1 \\
Shiner perch Cymatogaster aggregata & 3.0 \\
Threespine stickleback Gasterosteus aculeatus & 1.3 \\
Chum salmon Oncorhynchus keta & 0.7 \\
Staghorn sculpin Leptocottus armatus & 0.6 \\
Surf smelt Hypomesus pretiosus & 0.4 \\
Coho salmon O. kisutch & 0.3 \\
Pink salmon O. gorbuscha & 0.3 \\
Snake prickleback Lupenus sagitta & 0.2 \\
Chinook salmon O. tshawytscha & 0.2 \\
Tadpole sculpin Psychrolutes paradoxus & $<0.1$ \\
Northern anchovy Engraulis mordax & $<0.1$ \\
Longfin smelt Spirinchus thaleichthys & 0 \\
Soft sculpin Gilbertidia sigalutes & 0 \\
& \\
\hline
\end{tabular}

the major source of backscatter (e.g. Vermeer et al. 1987, Coyle et al. 1992). Finally, acoustic targets at depth moved very quickly out of the acoustic beam and away from sash weights or other objects (such as conductivity-temperature-depth probes or plankton nets) dropped towards them from the water's surface. Such avoidance behavior indicates that the targets are small fishes, as it is extremely unlikely that euphausiids, copepod aggregations, bubbles, sediment, or detritus would react to falling objects in this manner.

I analyzed 4 different measures of prey availability to feeding flocks: total backscatter $\left(\sigma_{\mathrm{bs}}\right) \mathrm{m}^{-1}$ of transect, integrated over all depths; total backscatter $\mathrm{m}^{-1}$ transect, integrated in the top 10 depth strata only (depths approximately 2 to $12 \mathrm{~m}$ ); encounter probability, integrated overall depths; and encounter probability in the top 10 depth strata only. Total backscatter was used as a measure of relative fish biomass in the water column. I chose to include a separate analysis of the top 10 depth strata because rhinoceros auklets - a diving predator observed with $90 \%$ of feeding flocks - spend $90 \%$ of their dive time in the top $10 \mathrm{~m}$ even though they are able to dive to depths of $60 \mathrm{~m}$ (Burger et al. 1993). Therefore, changes in fish biomass or encounter probabilities below $10 \mathrm{~m}$ may not have a large effect on prey availability to mixed-species flocks. I chose encounter probability as an alternative measure of prey availability because predators with incomplete information about prey distributions are more likely to estimate encounter proba- 
Table 4. Species composition of feeding flocks from Cattle Pass. Data are from 60 flocks for which accurate counts of all flock members, including diving birds, were available; $\mathrm{n}=$ mean no. of individuals per flock. Percent occurrence for harbor seals and dogfish was obtained from sample of 32 flocks for which close approaches were made with a small boat (see Zamon 2001 for details). It was not possible to obtain a quantitative estimate of the number of dogfish associated with a flock; but 3 to 15 individuals could typically be seen from the surface

\begin{tabular}{|lcc|}
\hline Species & \% occurrence & $\mathrm{n}$ \\
\hline Glaucous-winged gull Larus glaucescens & 98.3 & 20.3 \\
Rhinoceros auklet Cerorhinca monocerata & 90.0 & 11.4 \\
Heermann's gull L. heermanni & 78.3 & 11.2 \\
Harbor seal Phoca vitulina & 40.6 & 0.3 \\
Cormorant Phalacrocorax sp. & 40.0 & 1.0 \\
Spiny dogfish Squalus acanthias & 39.3 & - \\
Common murre Uria aalge & 30.0 & 2.7 \\
Bonaparte's gull L. philadelphia & 5.0 & 0.6 \\
Mew gull L. canus & 1.7 & 0.02 \\
Herring gull L. argentus & 1.7 & 0.02 \\
Mean flock size & & 47.5 \\
\hline
\end{tabular}

bilities than estimate a parameter such as biomass, and patchiness of prey can have effects on encounter probability that are independent of biomass (Stephens \& Krebs 1986, Zamon et al. 1996). I define 'encounter probability' as the proportion of 1-report-by-1-stratum bins ( $\sim 30 \mathrm{~m} \times$ $1 \mathrm{~m})$ containing non-zero backscattering values. For example, a transect containing 50 horizontal reports and 10 depth strata would have 500 bins; if 250 of those bins contained non-zero backscattering values, the encounter probability would be 0.5 , or $50 \%$.

Although gulls are not likely to reach fishes deeper than 1 to $2 \mathrm{~m}$ during surface feeding or plunging, 9 out of 10 summer feeding flocks also included rhinoceros auklets, a diving predator (Table 4). Subsurface fishes can be made available to gulls by these auklets when the latter chase fishes to the surface and trap them there (e.g. Hoffman et al. 1981, Grover \& Olla 1983). In addition, gulls are capable of tracking subsurface schools even though they may not be able to reach them; this phenomenon also occurs in the eastern tropical Pacific, where surface-feeding seabirds successfully follow diving predators and forage fishes as they move over large areas (e.g. Au \& Pitman 1986).

Goodness-of-fit analyses of the different prey availability measures were entirely analogous to those described for feeding flocks: transects were classified within an $8 \times 2$ contingency table where the 2 factors were tidal phase (8 classes: Table 1 ) and prey availability ( 2 classes: negative prey anomalies, positive prey anomalies). However, because each measure of prey availability was not statistically independent of other measures, $p$-values from individual goodness-of-fit tests were arranged in the order from smallest to largest, and a sequential Dunn-Šidák correction was applied to ob- tain a comparison-wide $\alpha=0.05$. These corrected comparisons were then examined to determine whether any prey availability anomaly was significantly associated with tidal phase (Sokal \& Rohlf 1995).

\section{RESULTS}

\section{Feeding-flock activity: aerial counts}

Although sample sizes were limited by the number of seaplane surveys available, feeding activity in the San Juan archipelago was greater during the flood tide (mean $=48.7$ flocks) than during the ebb tide (mean $=16.3$ flocks). Significantly more flocks were present in the archipelago during the maximum flood current than during the maximum ebb current in 1994 (Table 5; sign-test, $\mathrm{p}<0.01$ ).

\section{Feeding flock activity: land-based counts}

Between 1994 and 1997, 726 thirty min periods were sampled. A total of 2134 flock feeding events were counted. Feeding activity varied between 0 and 47 flocks per $30 \mathrm{~min}$. Accurate counts of entire flocks were available from 60 flocks occurring within $100 \mathrm{~m}$ of the land-based observation site. Based on these 60 flocks, mean flock size was 47.5 individuals. Glaucous-winged gulls, Heermann's gulls, and rhinoceros auklets were the dominant predators, accounting for $80 \%$ or more of summer flock membership (Table 4 ). The distribution of raw count data among tidal categories (flocks per 30 min observation period) is shown in Fig. 5. Median counts were highest (3 flocks per 30 min) during Slow flood 1 and Fast flood.

The goodness-of-fit test showed that feeding anomalies were significantly associated with tidal phase

Table 5. Aerial counts of flocks, as a function of maximum flood and maximum ebb current. -: no seaplane survey conducted on that date

\begin{tabular}{|lcc|}
\hline Date (1994) & Max. flood current & Max. ebb current \\
\hline 27 Jun & 38 & - \\
29 Jun & 32 & - \\
$25 \mathrm{Jul}$ & 70 & 9 \\
$26 \mathrm{Jul}$ & 55 & 15 \\
$27 \mathrm{Jul}$ & 88 & 25 \\
$24 \mathrm{Aug}$ & 33 & - \\
$25 \mathrm{Aug}$ & 25 & - \\
\hline
\end{tabular}




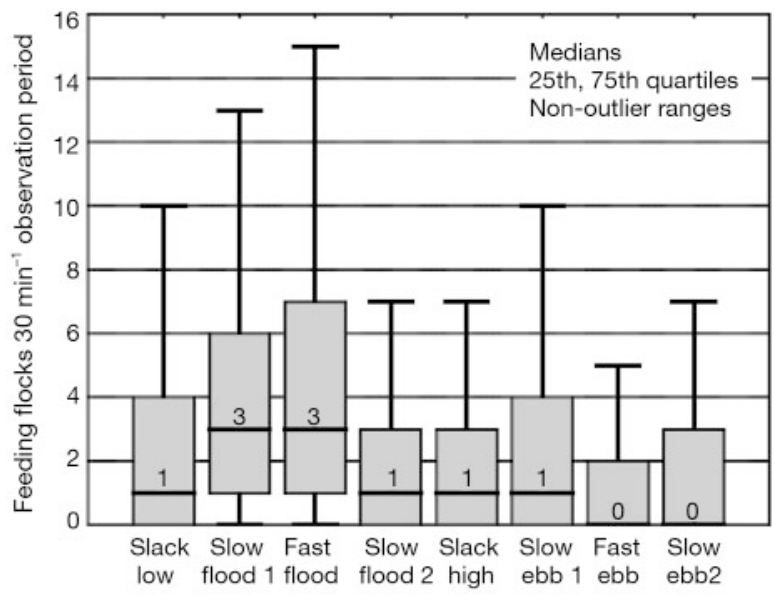

Fig. 5. Numbers of feeding flocks as a function of tidal phase, raw data; data from all years pooled. Numbers within bars indicate median counts for individual tide categories. Counts $>75$ th percentile $+[1.5 \times$ (value of 75 th percentile - value of 25th percentile)] were considered outliers; these were included in analysis but are not plotted on this graph. Tidal phases and velocities classified as in Table 1

(Table 6: $\chi^{2}=28.3$, df $=7, \mathrm{p}<0.001$ ). More positive anomalies than expected were observed during Slow flood 1 and Fast flood; fewer positive anomalies than expected were observed during Fast ebb and Slow ebb 2 (Fig. 6).

\section{Prey availability}

During 1995 through 1997, 145 acoustic transects were completed along Line HR, and 123 transects were completed along Line HP. Because median backscatter values in each tidal category for Transect HP were always greater than median values for Transect HR (data not shown), I decided to analyze HR and HP separately. Total water column backscatter $\left(\sigma_{\mathrm{bs}}\right) \mathrm{m}^{-1}$ tran- sect varied from 0 to $7.18 \times 10^{-4}$ on Transect HR and 0 to $2.28 \times 10^{-4}$ on Transect HP. Total water-column encounter probabilities varied from 0.001 to 0.265 on Transect HR and 0.004 to 0.338 on Transect HP. The distributions of raw encounter probability data among tidal categories are shown in Fig. 7. The highest median encounter probabilities occurred during either Slow flood 1 (all depths $=0.08$ for HP) or Fast flood (all depths $=0.4$ for $\mathrm{HR}_{i} 2$ to $12 \mathrm{~m}=0.11$ for $H R, 0.19$ for HP). Raw backscatter data are not shown because backscatter anomalies did not show significant associations with tidal phase (see next paragraph); however, the highest values of median backscatter $\mathrm{m}^{-1}$ transect also occurred during Slow flood 1 ( 2 to $12 \mathrm{~m}=3.1 \times 10^{-7}$ for HR) or Fast flood phases (all depths $=4.3 \times 10^{-6}$ for $\mathrm{HR}_{i} 7.8 \times 10^{-6}$ for HP; 2 to $12 \mathrm{~m}=3.0 \times 10^{-6}$ for $\mathrm{HP}$ ).

Results from the goodness-of-fit tests for prey availability anomalies vs tidal phase are presented in Tables 7 to 10. Backscatter anomalies were not strongly associated with tidal phase on either transect, whereas encounter anomalies were significantly associated with tidal phase on both transects (Table 11). More positive encounter anomalies than expected occurred during Fast flood. Fewer positive encounter anomalies than expected occurred during Slow ebb 1 and Slow ebb 2 (Fig. 8).

\section{DISCUSSION}

The association of positive feeding anomalies with flood tides supports the idea that piscivorous feedingactivity is coupled to tidal cycles. The association of positive prey encounter anomalies with flood tides further supports the idea that this increase in feeding activity is related to increased fish availability. However, it is important to note that while positive encounter anomalies exhibited significant association with the flood tide, positive backscatter anomalies did not. These results imply that, during flood tides, fishes

Table 6. Contingency table for feeding anomaly versus tidal phase (see Table 1 for classification of tidal velocities). Null hypothesis of no association of feeding anomaly with tidal phase was rejected $\left(\chi^{2}=28.3, \mathrm{df}=7, \mathrm{p}<0.001\right)$

\begin{tabular}{|lcccr|r|}
\hline Tidal phase & \multicolumn{2}{c|}{$\begin{array}{c}\text { Negative feeding anomalies } \\
\text { Observed }\end{array}$} & Expected & \multicolumn{2}{c|}{$\begin{array}{c}\text { Positive feeding anomalies } \\
\text { Observed }\end{array}$} \\
\hline Slack low & 15 & 15.7 & 20 & 19.3 & 35 \\
Slow flood 1 & 22 & 29.1 & 43 & 35.9 & 65 \\
Fast flood & 38 & 54.7 & 84 & 67.3 & 122 \\
Slow flood 2 & 19 & 17.9 & 21 & 22.0 & 40 \\
Slack high & 17 & 16.1 & 19 & 41.9 & 75 \\
Slow ebb 1 & 37 & 33.6 & 38 & 33.7 & 61 \\
Fast ebb & 35 & 27.4 & 15 & 26.5 & 48 \\
Slow ebb 2 & 33 & 21.5 & 266 & 266 & 482 \\
Totals & 216 & 216 & & \\
\hline
\end{tabular}




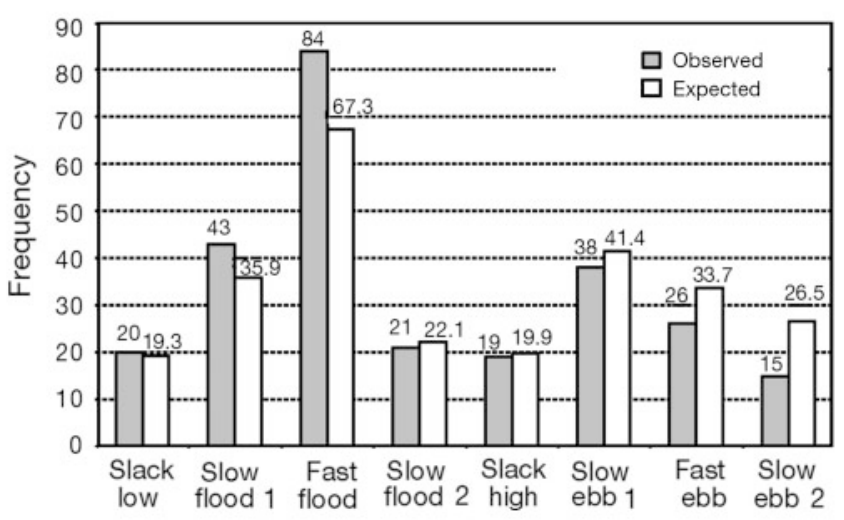

Fig. 6. Observed and expected frequencies of positive feeding anomalies as a function tidal phase. Numbers above bars: no. of counts water camera deployments passing near fish schools clearly showed fishes orienting into the current, performing C-start behaviors, and biting actively. Similar feeding behavior was observed in near-surface schools of both herring and sandlance seen from the boat when the boat was drifting without the motor running.

Actively feeding fishes are also likely to be more vulnerable to visual predators than non-feeding fishes. C-start postures associated with feeding strikes of sandlance are known to cause a silvery flash visible many fish body-lengths away (Denton \& Rowe 1994). These flashes may make fishes easier for a predator to detect. The effect of fishes feeding behavior on visibility or vulnerability to seabird predators has not been studied, although the 'silvery flash' is a visual cue exploited by sport and commercial fishermen when become more dispersed in the water column, but not necessarily more abundant. Therefore, changes in fish abundance alone may not be driving food availability to fish predators, as originally implied in the tidal-coupling hypothesis. The data suggest that fish distribution or behavior also affects their availability to predators.

In Cattle Pass, the most likely cause of fishes dispersing into the water column is a feeding response. Sandlance schools are known to become relatively stationary and increase nearest-neighbor distances when they feed on plankton (Robards et al. 1999 and references therein). Copepods, the primary prey of juvenile herring and sandlance, are significantly more abundant in Cattle Pass during flood tides than during ebb tides (Zamon 2002). The association of flooding tidal currents with increased copepod abundance could therefore cause increased feeding activity of planktivores during the flood. This type of behavioral response has been qualitatively described for mixed schools of herring and sandlance in Alaska (Hobson 1986).

Feeding responses of planktivorous fishes to changing currents are often reported in the literature on reef fishes (e.g. Bray 1981, Kingsford \& MacDiarmid 1988, Kingsford et al. 1991, Noda et al. 1992, 1994, Shapiro \& Genin 1993, Anderson \& Sabado 1995), but infrequently studied in non-reef species (for an exception, see Simard et al. 2002). Although it was not possible to quantify fish-feeding behavior directly, evidence indicated that fishes were actively feeding in Cattle Pass. A study of gut contents revealed that patterns of sandlance gut-fullness were consistent with daytime feeding on plankton in the Cattle Pass area (O'Reilly 1997). Two under-
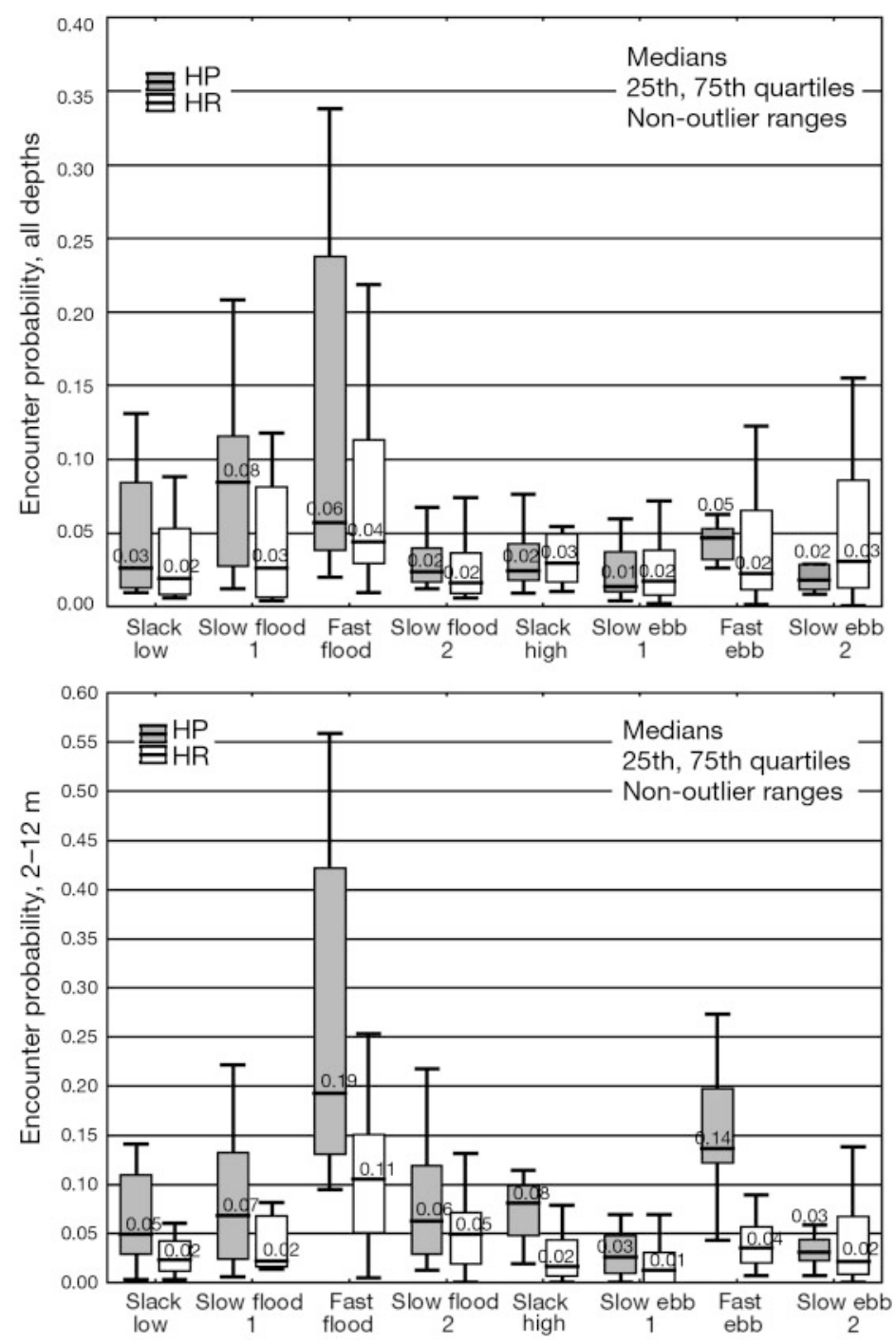

Fig. 7. Encounter probabilities per transect as a function of tidal phase; raw data; data from all years pooled. Further details as in Fig. 5 
Table 7. Contingency table for backscatter anomaly versus tidal phase, all depths. Null hypothesis of no association of backscatter anomaly with tidal phase was not rejected after Dunn-Šidák corrections for non-independent comparisons (HR transect: $\chi^{2}=11.4, \mathrm{df}=7, \mathrm{p}=0.12 ; \mathrm{HP}$ transect: $\chi^{2}=14.5, \mathrm{df}=7, \mathrm{p}=0.04$ )

\begin{tabular}{|c|c|c|c|c|c|c|c|c|c|c|}
\hline \multirow{3}{*}{$\begin{array}{l}\text { Tidal phase } \\
\text { Transect }\end{array}$} & \multicolumn{4}{|c|}{ Negative backscatter anomalies } & \multicolumn{4}{|c|}{ Positive backscatter anomalies } & \multirow{2}{*}{\multicolumn{2}{|c|}{ Total }} \\
\hline & \multicolumn{2}{|c|}{ Observed } & \multicolumn{2}{|c|}{ Expected } & \multicolumn{2}{|c|}{ Observed } & \multicolumn{2}{|c|}{ Expected } & & \\
\hline & HR & HP & HR & HP & HR & HP & HR & HP & HR & $\mathrm{HP}$ \\
\hline Slack low & 4 & 5 & 3.3 & 5.0 & 3 & 5 & 3.7 & 5.0 & 7 & 10 \\
\hline Slow flood 1 & 5 & 7 & 4.8 & 8.0 & 5 & 9 & 5.2 & 8.0 & 10 & 16 \\
\hline Fast flood & 7 & 0 & 13.8 & 3.5 & 22 & 7 & 15.2 & 3.5 & 29 & 7 \\
\hline Slow flood 2 & 9 & 11 & 8.1 & 11.5 & 8 & 12 & 8.9 & 11.5 & 17 & 23 \\
\hline Slack high & 9 & 6 & 6.7 & 5.0 & 5 & 4 & 7.3 & 5.0 & 14 & 10 \\
\hline Slow ebb 1 & 10 & 11 & 9.6 & 9.0 & 10 & 7 & 10.5 & 9.0 & 20 & 18 \\
\hline Fast ebb & 5 & 1 & 6.2 & 3.0 & 8 & 5 & 6.8 & 3.0 & 13 & 6 \\
\hline Slow ebb 2 & 13 & 14 & 9.5 & 10.0 & 7 & 6 & 10.4 & 10.0 & 20 & 20 \\
\hline Total & 62 & 55 & 62.0 & 55.0 & 68 & 55 & 68.0 & 55.0 & 130 & 110 \\
\hline
\end{tabular}

Table 8. Contingency table for backscatter anomaly versus tidal phase, 2 to $12 \mathrm{~m}$. Null hypothesis of no association of surface backscatter anomaly with tidal phase was not rejected after Dunn-Šidák corrections for non-independent comparisons (HR transect: $\chi^{2}=5.8, \mathrm{df}=7, \mathrm{p}=0.56$; HP transect: $\chi^{2}=13.9, \mathrm{df}=7, \mathrm{p}=0.05$ )

\begin{tabular}{|c|c|c|c|c|c|c|c|c|c|c|}
\hline \multirow{3}{*}{$\begin{array}{l}\text { Tidal phase } \\
\text { Transect }\end{array}$} & \multicolumn{4}{|c|}{ Negative backscatter anomalies } & \multicolumn{4}{|c|}{ Positive backscatter anomalies } & \multicolumn{2}{|c|}{ Total } \\
\hline & \multicolumn{2}{|c|}{ Observed } & \multicolumn{2}{|c|}{ Expected } & \multicolumn{2}{|c|}{ Observed } & \multicolumn{2}{|c|}{ Expected } & \multirow[b]{2}{*}{ HR } & \multirow[b]{2}{*}{$\mathrm{HF}$} \\
\hline & HR & HP & $\mathrm{HR}$ & HP & HR & HP & HR & HP & & \\
\hline Slack low & 3 & 2 & 3.3 & 5.0 & 4 & 8 & 3.7 & 5.0 & 7 & 10 \\
\hline Slow flood 1 & 4 & 10 & 4.8 & 7.5 & 6 & 5 & 5.2 & 7.5 & 10 & 15 \\
\hline Fast flood & 9 & 2 & 12.9 & 4.0 & 18 & 6 & 14.1 & 4.0 & 27 & 8 \\
\hline Slow flood 2 & 7 & 13 & 8.1 & 10.0 & 10 & 7 & 8.9 & 10.0 & 17 & 20 \\
\hline Slack high & 9 & 4 & 6.7 & 5.5 & 5 & 7 & 7.3 & 5.5 & 14 & 11 \\
\hline Slow ebb 1 & 12 & 12 & 9.5 & 9.5 & 8 & 7 & 10.5 & 9.5 & 20 & 19 \\
\hline Fast ebb & 6 & 1 & 5.7 & 3.0 & 6 & 5 & 6.3 & 3.0 & 12 & 6 \\
\hline Slow ebb 2 & 10 & 11 & 9.0 & 10.5 & 9 & 10 & 10.0 & 10.5 & 19 & 21 \\
\hline Total & 60 & 55 & 60.0 & 55.0 & 66 & 55 & 66.0 & 55.0 & 126 & 110 \\
\hline
\end{tabular}

Table 9. Contingency table for encounter probability anomaly versus tidal phase, all depths. Null hypothesis of no association of encounter probability anomaly with tidal phase was rejected after Dunn-Šidák corrections for non-independent comparisons (HR transect: $\chi^{2}=26.3, \mathrm{df}=7, \mathrm{p}<0.001$; HP transect: $\chi^{2}=22.6, \mathrm{df}=7, \mathrm{p}=0.002$ )

\begin{tabular}{|c|c|c|c|c|c|c|c|c|c|c|}
\hline \multirow{3}{*}{$\begin{array}{l}\text { Tidal phase } \\
\text { Transect }\end{array}$} & \multicolumn{4}{|c|}{ Negative encounter probability anomalies } & \multicolumn{4}{|c|}{ Positive encounter probability anomalies } & \multicolumn{2}{|c|}{ Total } \\
\hline & \multicolumn{2}{|c|}{ Observed } & \multicolumn{2}{|c|}{ Expected } & \multicolumn{2}{|c|}{ Observed } & \multicolumn{2}{|c|}{ Expected } & \multirow[b]{2}{*}{ HR } & \multirow[b]{2}{*}{ HP } \\
\hline & HR & HP & HR & $\mathrm{HP}$ & HR & HP & HR & $\mathrm{HP}$ & & \\
\hline Slack low & 4 & 2 & 3.3 & 5.0 & 3 & 8 & 3.7 & 5.0 & 7 & 10 \\
\hline Slow flood 1 & 3 & 10 & 5.3 & 7.5 & 8 & 5 & 5.7 & 7.5 & 11 & 15 \\
\hline Fast flood & 4 & 2 & 13.8 & 4.0 & 25 & 6 & 15.2 & 4.0 & 29 & 8 \\
\hline Slow flood 2 & 10 & 13 & 7.6 & 10.0 & 6 & 7 & 8.4 & 10.0 & 16 & 20 \\
\hline Slack high & 11 & 4 & 6.2 & 5.5 & 2 & 7 & 6.8 & 5.5 & 13 & 11 \\
\hline Slow ebb 1 & 14 & 12 & 10.5 & 9.5 & 8 & 7 & 11.5 & 9.5 & 22 & 19 \\
\hline Fast ebb & 6 & 1 & 5.7 & 3.0 & 6 & 5 & 6.3 & 3.0 & 12 & 6 \\
\hline Slow ebb 2 & 10 & 11 & 9.6 & 10.5 & 10 & 10 & 10.4 & 10.5 & 20 & 21 \\
\hline Total & 62 & 55 & 62.0 & 55.0 & 68 & 55 & 68.0 & 55.0 & 130 & 110 \\
\hline
\end{tabular}

luring predators to attack gear such as spoons, jigs, and flashers.

It is unlikely that fish distribution in Cattle Pass was changing in response to temperature, salinity, or the vertical distribution of plankton, as has been observed for capelin Mallotus villosus in some situations (Marc- 
Table 10. Contingency table for encounter probability anomaly versus tidal phase, 2 to $12 \mathrm{~m}$. Null hypothesis of no association of encounter probability anomaly with tidal phase was rejected after Dunn-Šidák corrections for non-independent comparisons (HR transect: $\chi^{2}=20.6, \mathrm{df}=7, \mathrm{p}<0.004 ;$ HP transect: $\chi^{2}=26.1, \mathrm{df}=7, \mathrm{p}<0.001$ )

\begin{tabular}{|c|c|c|c|c|c|c|c|c|c|c|}
\hline \multirow{3}{*}{$\begin{array}{l}\text { Tidal phase } \\
\text { Transect }\end{array}$} & \multirow{2}{*}{\multicolumn{4}{|c|}{$\begin{array}{c}\text { Negative encounter probability anomalies } \\
\text { Observed }\end{array}$}} & \multicolumn{4}{|c|}{ Positive encounter probability anomalies } & \multirow{2}{*}{\multicolumn{2}{|c|}{ Total }} \\
\hline & & & & & $\mathrm{Ob}$ & ed & & & & \\
\hline & HR & $\mathrm{HP}$ & HR & $\mathrm{HP}$ & HR & $\mathrm{HP}$ & HR & HP & HR & $\mathrm{HP}$ \\
\hline Slack low & 4 & 4 & 3.5 & 5.0 & 3 & 6 & 3.5 & 5.0 & 7 & 10 \\
\hline Slow flood 1 & 4 & 8 & 5.0 & 8.0 & 6 & 8 & 5.0 & 8.0 & 10 & 16 \\
\hline Fast flood & 7 & 0 & 15.0 & 4.0 & 23 & 8 & 15.0 & 4.0 & 30 & 8 \\
\hline Slow flood 2 & 8 & 9 & 8.5 & 11.0 & 9 & 13 & 8.5 & 11.0 & 17 & 22 \\
\hline Slack high & 9 & 5 & 7.0 & 5.0 & 5 & 5 & 7.0 & 5.0 & 14 & 10 \\
\hline Slow ebb 1 & 17 & 14 & 10.0 & 8.5 & 3 & 3 & 10.0 & 8.5 & 20 & 17 \\
\hline Fast ebb & 7 & 0 & 6.0 & 3.0 & 5 & 6 & 6.0 & 3.0 & 12 & 6 \\
\hline Slow ebb 2 & 9 & 15 & 10.0 & 10.0 & 11 & 6 & 10.0 & 10.5 & 20 & 21 \\
\hline Total & 65 & 55 & 65.0 & 55.0 & 65 & 55 & 65.0 & 55.0 & 130 & 110 \\
\hline
\end{tabular}

Table 11. Summary statistics of prey availability tests for transects HR and HP. p-values are from goodness-of-fit tests for prey availability anomalies versus tidal phase in Tables 7 to 10. Sequential Dunn-Šidák correction was applied to obtain comparison-wide Type I error of $\alpha=0.05$

\begin{tabular}{|c|c|c|c|c|c|c|}
\hline \multirow{2}{*}{$\begin{array}{l}\text { Prey availability measure } \\
\text { Transect }\end{array}$} & \multicolumn{2}{|c|}{$\mathrm{p}$-value } & \multicolumn{2}{|c|}{$\begin{array}{l}\text { Associated } \alpha \text { for } \\
i \text { th comparison }\end{array}$} & \multicolumn{2}{|c|}{$\begin{array}{l}\text { Significant association } \\
\text { with tidal phase? }\end{array}$} \\
\hline & HR & $\mathrm{HP}$ & HR & HP & HR & HP \\
\hline Total backscatter, all depths & 0.1244 & 0.0437 & 0.025 & 0.025 & No & No \\
\hline Total backscatter, 2-12 m & 0.5639 & 0.0527 & 0.050 & 0.050 & No & No \\
\hline Encounter probability, all depths & 0.0005 & 0.0020 & 0.013 & 0.017 & Yes & Yes \\
\hline Encounter probability, $2-12 \mathrm{~m}$ & 0.0044 & 0.0005 & 0.017 & 0.013 & Yes & Yes \\
\hline
\end{tabular}

hand et al. 1999). Inside Cattle Pass, neither the water column nor plankton densities were strongly stratified during this study (temperature and salinity between $10-12^{\circ} \mathrm{C}$ and $30-31$ psu, respectively; plankton densities statistically homogeneous with depth: see Zamon 2002). It is also unlikely that strong currents were directly 'mixing' disoriented fishes throughout the water column, because during $4 \mathrm{yr}$ of study, disoriented, injured, or dead fishes were never observed near the surface or trapped within vortices, even during maximal currents (J. E. Zamon pers. obs.). It is possible that fishes changed their distribution to seek out preferred current velocities or other flow structures, independent of any feeding response. However, if that were the case, then one would have expected to see similar encounter probabilities on both flood and ebb tides; this was only the case for surface encounters during fast ebb on Transect HP (Fig. 7). To fully understand the mechanisms driving the observed tidal patterns in fish distribution, the links among field observations of school dispersion, vulnerability to predation, fish feeding behavior, and current-velocity structure need further study.

\section{General importance of tidal-coupling}

Studies of marine birds and mammals have shown that individual predators actively track tidal phase and also exhibit foraging-site fidelity to tide rips, jets, and areas of complex bathymetry (e.g. Braune \& Gaskin 1982, Irons 1998, Raum-Suryan \& Harvey 1998, Suryan \& Harvey 1998). Although the observations presented here were limited to the San Juan Islands, the congruence of positive predator feeding anomalies and positive prey-availability anomalies provides an explanation of why individual predators show tidal patterns in their foraging behavior: prey availability is significantly associated with tidal phase. Furthermore, planktivorous schooling fishes - such as herring and sandlance in this study - are keystone species linking zooplankton production to upper trophic levels in many regions of the world's oceans. Anecdotal and quantitative evidence of important tidal-coupling between piscivores and their fish prey can be found in the literature on tropical (e.g. Johannes 1981, Wolanski \& Hamner 1988), temperate (e.g. Uda \& Ishino 1958) and polar (e.g. Cairns \& Schneider 1990) seas as well 

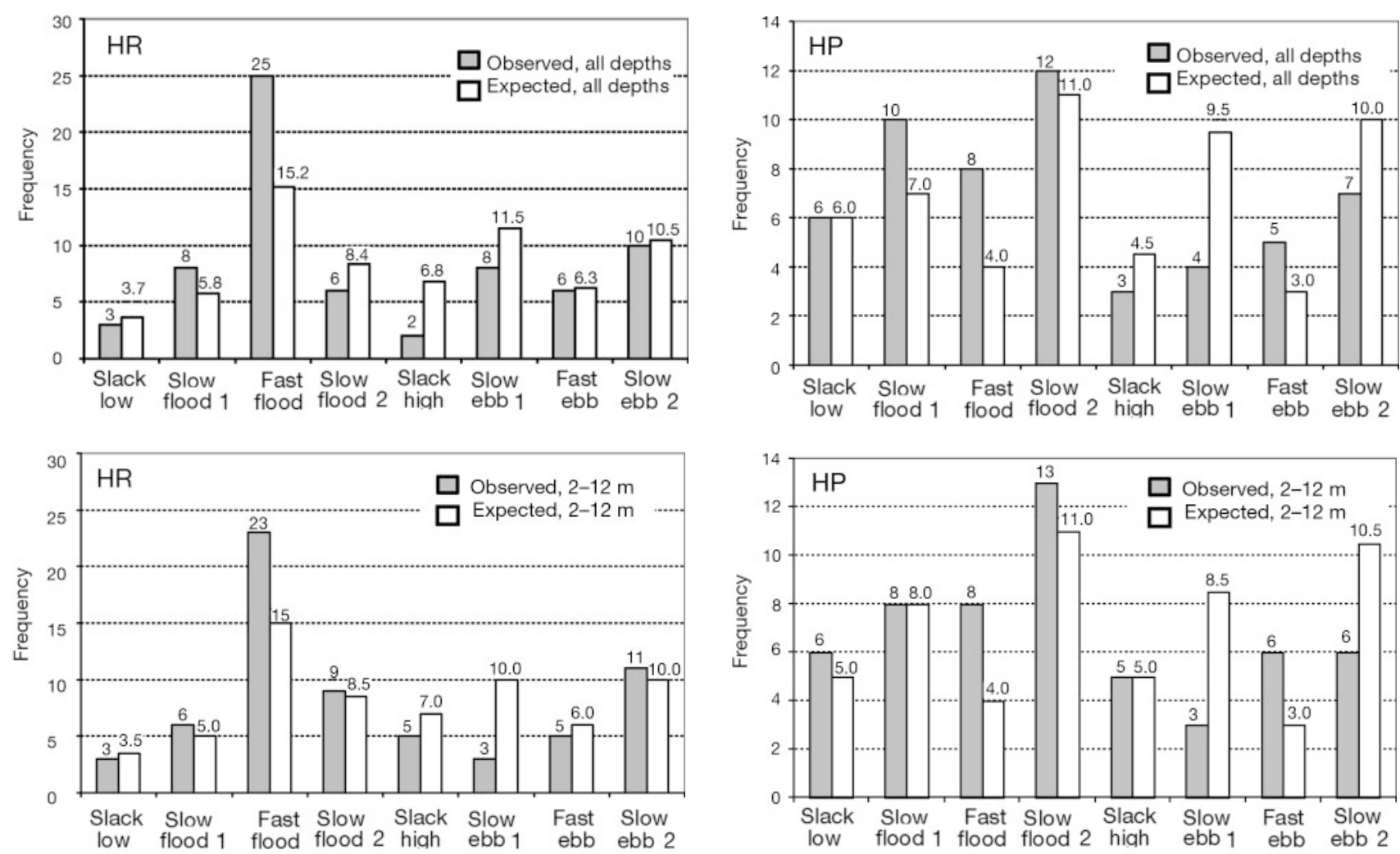

Fig. 8. Observed and expected positive prey-encounter anomalies as a function of tidal phase, for transects HR and HP; numbers above bars: no. of counts

as in estuaries (e.g. Marchand et al. 1999, Simard \& Lavoie 1999, Simard et al. 2002). Tidal channels, rips, and jets are often historically important feeding grounds and trophic 'hot spots' for marine predators (e.g. Lewis \& Sharpe 1987, Simard et al. 2002). These locations also have special significance as foraging habitats for breeding (Wilson \& Manuwal 1986, Wahl \& Speich 1994 and this study) and migratory (Braune \& Gaskin 1982 and this study) marine birds. Therefore, tidal-coupling across plankton $\rightarrow$ planktivorous-fishes $\rightarrow$ fish-predator linkages is likely to be an important general mechanism structuring nearshore marine predator-prey interactions and food web dynamics.

Acknowledgements. The author is extremely grateful for extensive field and logistical support provided by George and Peggy Hunt, the Cape San Juan Community, and Friday Harbor Laboratories (FHL). FHL Director A. O. Dennis Willows graciously piloted the seaplane used for aerial surveys. The crew of the RV 'Chaika' contributed many long days of assistance in the field: Heather Revilee, Lance Batch, Ian Brosnan, and Danney Grae. Elizabeth Venrick contributed statistically significant advice. George Hunt, Brad Hawkins, Bob Josephson, Loren Haury, and 3 anonymous reviewers provided critiques which significantly improved this manuscript. Funding for this work was provided by NSF grant DPP-9321636 to G. L. Hunt, a Holcomb Marine Science Scholarship, Frank M.
Chapman Awards, the Stafford Student Loan Program, a grant from the National Council of Paper Industry for Air \& Stream Improvement, and an EPA STAR Graduate Fellowship \#U915017-01-1 to J.E.Z.

\section{LITERATURE CITED}

Altmann J (1974) Observational study of behavior: sampling methods. Behaviour 69:227-267

Anderson TW, Sabado BD (1995) Correspondence between food availability and growth of a planktivorous temperate reef fish. J Exp Mar Biol Ecol 189:65-76

Au DWK, Pitman RL (1986) Seabird interactions with dolphins and tuna in the eastern tropical Pacific. Condor 88: $304-317$

BioSonics (1998) Visual analyzer. BioSonics, Seattle

Braune BM, Gaskin DE (1982) Feeding ecology of nonbreeding populations of larids off Deer Island, New Brunswick. Auk 99:67-76

Bray RN (1981) Influence of water currents and zooplankton densities on daily foraging movements of blacksmith, Chromis punctipinnis, a planktivorous reef fish. Fish Bull US 78:829-841

Brown RGB (1980) Seabirds as marine animals. In: Burger J, Olla BL, Winn HE (eds) Behavior of marine animals, Vol 4. Plenum Press, New York, p 1-39

Burger AE, Wilson RP, Garnier D, Wilson MPT (1993) Diving depths, diet, and underwater foraging of rhinoceros auklets in British Columbia. Can J Zool 71:2528-2540 
Cairns DK, Schneider DC (1990) Hot spots in cold water: feeding habitat selection by birds. Stud Avian Biol 14:52-60

Coyle KO, Hunt GL Jr, Decker MB, Weingartner TJ (1992) Murre foraging, epibenthic sound scattering, and tidal advection over a shoal near St. George Island, Bering Sea. Mar Ecol Prog Ser 83:1-14

Denton EJ, Rowe DM (1994) Reflective communication between fish, with special reference to the greater sand eel, Hyperoplus lanceolatus. Phil Trans R Soc Lond B 334: 221-237

Farmer DM, D'Asaro EA, Trevorrow MV, Dairiki GT (1995) Three-dimensional structure in a tidal convergence front. Cont Shelf Res 15(13):1619-1673

Fresh KL (1979) Distribution and abundance of fishes occurring in the nearshore surface waters of northern Puget Sound, Washington. PhD thesis, University of Washington, Seattle

Grover JJ, Olla BL (1983) The role of the rhinoceros auklet (Cerorhinca monocerata) in mixed-species feeding assemblages of seabirds in the Strait of Juan de Fuca, Washington. Auk 100:979-982

Hobson ES (1986) Predation on the Pacific sandlance, Ammodytes hexapterus (Pisces: Ammodytidae), during the transition between day and night in southeastern Alaska. Copeia 1:223-236

Hoffman W, Heinemann D, Wiens JA (1981) The ecology of seabird feeding flocks in Alaska. Auk 98:437-456

Horne JK, Clay CS (1998) Sonar systems and aquatic organisms: matching equipment and model parameters. Can J Fish Aquat Sci 55:1296-1306

Hunt GL Jr, Mehlum F, Russell RW, Irons DB, Decker MB, Becker PH (1999) Physical processes, prey abundance, and the foraging ecology of seabirds. In: Adams NJ, Slowtow RH (eds) Proc 22nd Int Ornithol Congr. Birdlife S Africa, Johannesburg, p 2040-2056

Irons DB (1998) Foraging area fidelity of individual seabirds in relation to tidal cycles and flock feeding. Ecology 79: $647-655$

Johannes RE (1981) Words of the lagoon. University of California Press, Berkeley

Kingsford MJ, MacDiarmid AB (1988) Interrelations between planktivorous reef fish and zooplankton in temperate waters. Mar Ecol Prog Ser 48:103-117

Kingsford MJ, Wolanski E, Choat JH (1991) Influence of tidally induced fronts and Langmuir circulations on distribution and movements of presettlement fishes around a coral reef. Mar Biol 109:167-180

Lewis MG, Sharpe FA (1987) Birding in the San Juan Islands. The Mountaineers, Seattle

Marchand C, Simard Y, Gratton Y (1999) Concentration of capelin (Mallotus villosus) in tidal upwelling fronts at the head of the Laurentian Channel in the St. Lawrence estuary. Can J Fish Aquat Sci 56:1832-1848

Medwin H, Clay CS (1998) Fundamentals of acoustical oceanography. Academic Press, New York

Nautical Software (1996) Tides and currents, version 2.5. Nautical Software, Beaverton, OR

Noda M, Kawabata K, Gushima K, Kakuda S (1992) Importance of zooplankton patches in foraging ecology of the planktivorous reef fish Chromis chrysurus (Pomacentridae) at Kuchinoerabu Island, Japan. Mar Ecol Prog Ser 87: 251-263

Noda M, Gushima K, Kakuda S (1994) Local prey search based on spatial memory and expectation in the planktivorous reef fish, Chromis chrysurus (Pomacentridae). Anim Behav 47:1413-1422

Editorial responsibility: Michael Landry (Contributing Editor), Honolulu, Hawaii, USA
O'Reilly KM (1997) Sunrise and sunset gut volume comparisons, field observations and predator avoidance of Pacific sandlance, Ammodytes hexapterus, at San Juan Island, Washington. School of Fisheries, University of Washington, Seattle

Raum-Suryan KL, Harvey JT (1998) Distribution and abundance of and habitat use by harbor porpoise, Phocoena phocoena, off the northern San Juan Islands, Washington. Fish Bull US 96:808-822

Robards MD, Wilson MF, Armstrong RH, Piatt JF (1999) Sand lance: a review of biology and predator relations and annotated bibliography. Res Pap PNW-RP-521, USDA. Forest Service, Pacific Northwest Research Station, Portland, OR

Shapiro DY, Genin A (1993) Feeding whorl induced by strong current in a planktivorous reef fish. Copeia 1993: $542-545$

Simard Y, Lavoie D (1999) The rich krill aggregation of the Saguenay -St. Lawrence Marine Park: hydroacoustic and geostatistical biomass estimates, structure, variability, and significance for whales. Can J Fish Aquat Sci 56: $1182-1197$

Simard Y, Lavoie D, Saucier FJ (2002) Channel head dynamics:capelin (Mallotus villosus) aggregation in the tidally driven upwelling system of the Saguenay - St. Lawrence Marine Park's whale feeding ground. Can J Fish Aquat Sci 59:197-210

Sokal RR, Rohlf FJ (1995) Biometry. The principles and practice of statistics in biological research, 3rd edn. WH Freeman, New York

Stephens DW, Krebs JR (1986) Foraging theory. Princeton University Press, Princeton

Suryan RM, Harvey JT (1998) Tracking harbor seals (Phoca vitulina Richardsi) to determine dive behavior, foraging activity, and haul-out site use. Mar Mamm Sci 14: 361-372

Thomas GL, Kirsch J, Thorne RE (2002) Ex situ target strength measurements of Pacific herring and Pacific sand lance. N Am J Fish Manag 22:1136-1145

Uda M, Ishino M (1958) Enrichment patterns resulting from eddy systems in relation to fishing grounds. J Tokyo Univ Fish 44:105-129

Vermeer K, Szabo I, Greisman P (1987) The relationship between plankton-feeding Bonaparte's and Mew Gulls and tidal upwelling at Active Pass, British Columbia. J Plankton Res 9:483-501

Wahl TR, Speich SM (1994) Distribution of foraging rhinoceros auklets in the Strait of Juan de Fuca, Washington. Northwestern Nat 75:63-69

Wilson UW, Manuwal DA (1986) Breeding biology of the rhinoceros auklet in Washington. Condor 88:143-155

Wolanski E, Hamner WM (1988) Topographically controlled fronts in the ocean and their biological influence. Science 241:177-181

Zamon JE (2001) Seal predation on salmon and forage-fish schools as a function of tidal currents in the San Juan Islands, Washington, USA. Fish Oceanogr 10:353-366

Zamon JE (2002) Tidal changes in copepod abundance and maintenance of a summer Coscinodiscus bloom in the southern San Juan Channel, San Juan Islands, USA. Mar Ecol Prog Ser 226:193-210

Zamon JE, Greene CH, Meir E, Demer DA, Hewitt RP, Sexton $S$ (1996) Acoustic characterization of the three-dimensional prey field of foraging chinstrap penguins. Mar Ecol Prog Ser 131:1-10

Submitted: May 31, 2002; Accepted: May 5, 2003

Proofs received from author(s): September 23, 2003 